\title{
Family and Feminism in Ursula K. Le Guin's The Dispossessed
}

\section{By Natalie Kuss}

$\cos$

\section{ABSTRACT}

The current American familial structure consists of a mother who serves as the housewife and

a father who serves as the breadwinner. Although American society is breaking away from this norm, the nuclear family structure is still idealized, causing women to struggle against the patriarchal confines of this structure as they choose to remain single, enter the workforce, and refuse to reproduce. Ursula K. Le Guin's The Dispossessed utilizes the utopia genre to explore a fictional planet, Anarres, that values collectivism over individualism in an attempt to become truly egalitarian. This essay analyzes the egalitarian structure of Anarres through the experiences of the main character, Shevek, and uses it to examine the anti-feminist issues of the current familial structure of America. 


\section{INTRODUCTION}

The stereotypical, idealized version of the American family includes a mother who remains inside of the home and a father who acts as the sole "breadwinner." This romanticized idea of the American family has prevented and discouraged women from pursuing their desires outside of the home for centuries. Although many Americans boast about the gender equality of the United States, others believe America must continue to develop as a society before it can be considered truly egalitarian, due to the patriarchal structure of the country that still exists today. The long-held belief that the stereotypical nuclear family structure must prevail continues to make real gender equality impossible. The struggle between following the status quo of forming the traditional family and the desire to break free from the pressures of society is reflected within current utopian literature and film. Consequently, theories about what changing this structure would do to a society continue to develop.

Ursula K. Le Guin utilizes the utopian narrative of her novel The Dispossessed to promote collectivism over traditional familial bonds as a model to achieve an egalitarian, feminist society. The anarchical structure of Le Guin's fictional planet Anarres helps the reader imagine how society would change and evolve if the current ideal family structure was removed and replaced with an egalitarian, collectivist model. By creating a world where men and women are truly equal, she creates a blueprint for how feminism can emerge and thrive in a new social structure unlike our own and imagines how this change affects traditional familial structures.

The Dispossessed challenges the ideal American family and proposes that its current structure prevents the formation of an egalitarian society.

\section{LIFE OF ANARRES-A BRIEF SUMMARY OF THE DISPOSSESSED}

Anarres is a unique planet within the world Ursula K. Le Guin constructs in The Dispossessed. We discover more about Anarres from the experiences of the main character of the novel, Shevek. Shevek is a physicist who travels from his home planet of Anarres to Urras in order to complete his theory on a device that would allow for instant communication between planets. Anarres was founded by Odo, a woman who was imprisoned on Urras for her radical ideas of collectivism until her eventual 
release. This division between Urras and Anarres has created tension between the two planets to the point that only one port exists to allow the entry and exit of goods shared between them.

In comparison to the individualistic nature of Urras, the Anarresti value collectivism and have structured their society around the idea that everyone must work together towards the betterment of the planet as a whole. This has drastically affected the way their government and laws are structured. In her article "Mapping the Walls of the Dispossessed," Sandra Lindow describes the judicial system of Anarres as "a loose system of committees based on a kind of town hall democracy where individuals must state their cases and convince others of the validity of their needs" (175). Anarresti are free from the confines of law and government. Shevek himself provides evidence of this structure during a conversation with one of his childhood friends, Tirin. He states:

Are we kept here by force? What force-what laws, governments, police? None. Simply our own being, our nature as Odonians. It's your nature to be Tirin, and my nature to be Shevek, and our common nature to be Odonians, responsible to one another. And that responsibility is our freedom. To avoid it, would be to lose our freedom. (Le Guin 40)

This quotation further indicates that Anarres is structured as a collectivist, egalitarian, and anarchical society. The Anarresti value freedom above all, allowing them to act in accordance with their own wills.

Through Anarres' efforts to become more egalitarian, women are treated equally to men and, therefore, the structure of Anarres supports the concepts of feminism as well. This is also evidenced by Shevek during a conversation he has on his trip to Urras with his guide, Dr. Kimoe. Shevek is told that there are no women on the ship because that type of employment is not considered "women's work" on Urras. Dr. Kimoe proceeds to question the roles of men and women on Anarres in response to Shevek:

Kimoe tried to explain status, failed, and went back to the first topic. "Is there really no distinction between men's work and women's work?”

“Well, no, it seems a very mechanical basis for the division of labor, doesn’t it? A person chooses work according to interest, talent, strength-what has the sex to do with that?” "Men are physically stronger," the doctor asserted with professional finality. 
"Yes, often, and larger, but what does that matter when we have machines? And even when we don't have machines, when we must dig with the shovel or carry on the back, the men maybe work faster-the big ones- but the women work longer. ... Often I have wished I was as tough as a woman.” (Le Guin 20)

Shevek's explanation shows that all genders are valued on Anarres because they are judged on their ability to help the planet, not whether or not they are male or female. As long as they can provide beneficial support to the planet, they are considered equal.

\section{FAMILY ON ANARRES}

In their efforts to collectivize, the Anarresti have redefined the concept of family, creating an opposition to the traditional familial structure of American society. The community raises each child through various institutions created with the aim to better the society as a whole, which leaves both men and women free to pursue their own interests outside of the home. The reader is introduced to these organizations through flashbacks to Shevek's childhood. In one flashback, Shevek is left by his father, Palat, to be raised in a nursery when his mother, Rulag, is given a job in a distant location. When Palat drops Shevek off at the nursery, the following dialogue occurs between him and a nurse:

"The mother's been posted to Abbenay," the man says. "She wants him to stay here."

"Shall we take him into the nursery full-time, then, Palat?"

"Yes. I'll be moving back into a dorm."

“Don’t worry, he knows us all here! But surely Divlab will send you along after Rulag soon? Since you're partners, and both engineers?”

"Yes, but she's ... It's the Central Institute of Engineering that wants her, see. I'm not that good. Rulag has a great work to do" (Le Guin 27)

This conversation reveals that Rulag's work, which is implied to be important to Anarres by Palat's response, takes precedence over raising Shevek. Shevek is "taken full-time," suggesting that he will no longer be raised by his parents. The Anarresti have attempted to remove the need for parents to remain with their children and replace it with a collective responsibility of the society to raise them instead. By doing so, the people of Anarres free women from the confines of the traditional American 
family structure, where they would be pressured to remain in the home to raise their child. The removal of the traditional American maternal figure in the family may bring about questions of how this may affect the child. Many who support women remaining in the home believe that without a mother present, the child's mental and emotional health may be negatively impacted. In opposition to the argument that children require a mother figure to properly function and mature, Kathleen Gerson, in her article, "Resolving Family Dilemmas and Conflicts: Beyond Utopia," states that "Decades of research have shown consistently that employed mothers pose no harm to their children and, to the contrary, offer significant benefits" (182). Gerson supports the idea that children who are separated from their mothers actually benefit from this separation instead of being harmed by it. Her argument provides opposition to the strongly held American belief that a maternal figure is necessary to produce successful individuals.

The idea that maternal figures are not necessary to raise successful children is also promoted by The Dispossessed. Shevek leads a generally fulfilling life, even after being raised without his parents' presence. He forms friendships with Tirin and Bedap during his time at school that last for the duration of the novel. Shevek finds a life partner, Takver, and they have children, further exemplifying his ability to form lasting relationships and properly convey affection towards others. He is able to travel to Urras and complete his communication device, proving his ability to be successful and make an impact on not only the society of Anarres, but also on the entire universe within the novel. Although Shevek struggles to find his place within his own society, he eventually finds a path to happiness and fulfillment.

The structure of Anarres continues to break down the traditional stereotypes of the American family by promoting non-traditional relationships. Instead of marrying and forming nuclear families, most citizens of Anarres do not commit themselves to one person for their entire life. They are free to "copulate," as they call it on Anarres, with whomever they want, whenever they want. This concept frees women from the idea that they must be partnered to one man to form a family and commit themselves to the role of housewife to ensure the success of the nuclear family and society as a whole. Anarresti women are removed from the typical judgement that women currently face in American society for being too promiscuous, as Anarres is more focused on the betterment of the society than 
the individual. This idea is reflected in Rulag's own success away from her family. When Shevek finally encounters her again as an adult, she is part of the PDC, one of the most influential institutions on Anarres. Rulag makes a name for herself away from her family, becoming one of Bedap's (a colleague and friend of Shevek's) and Shevek's toughest opponents when they want to travel to Urras. The narrator states:

Somebody had told Bedap that Rulag was an engineer, and he had found in her the engineer's clarity and pragmatism of mind, plus the mechanist's hatred of complexity and irregularity. She opposed the Syndicate of Initiative on every issue, including that of its right to exist. Her arguments were good, and Bedap respected her. Sometimes when she spoke of the strength of Urras, and the danger of bargaining with the strong from a position of weakness, he believed her. (Le Guin 263)

Rulag holds respect within Anarresti society, thus exemplifying women's success when not held back by the sexism that prevents them from advancement in American society today. Rulag's pursuit of power is supported by the people of Anarres because her efforts benefit the society as a whole. Without the belief that the betterment of society is more important than one's own pursuits, women like Rulag would possibly be confined to the home to raise their children instead of being allowed to enter the workforce to help improve life on Anarres. Anarresti women are free to pursue their own success as opposed to feeling obligated to ensure the success of their family. Le Guin breaks down gender norms promoted through the traditional American family structure by showing that pursuit of bettering a society does not discriminate based on gender.

\section{SUPPORT FOR FAMILIAL BONDS WITHIN COLLECTIVIST SOCIETIES}

Despite the benefits ascribed to a rejection of traditional family bonds in The Dispossessed, collectivism might also signal a loss in the form of the nuclear family and the potential loss of individual desires and pursuits for the cause of the collective. In this collective process, the role of the family unit within a society can become lost and misconstrued as it seems less important. Le Guin may show the benefits of collectivism for certain oppressed groups within American society, such as women and homosexuals, but leaves the reader questioning whether or not societies can be both 
collectivist and still maintain traditional familial structures that we are accustomed to today. I

In an effort to answer this question, other, we might turn to real world examples. In Christoph Brumann's article "All the Flesh Kindred that Ever I See,” the author examines societies that removed familial bonds entirely in favor of collectivism and compared them to societies that were both collectivist while promoting the formation of traditional families. His study directly correlates to Le Guin's own exploration of the effects of removing familial bonds in The Dispossessed. He analyzed the Shakers, a communal sect that developed from a Quaker splinter group that promoted collectivism through the weakening of familial bonds. He then compared them to other utopian communities, including the Hutterite colonies, the kibbutzim, and the Bruderhof, who promoted both collectivism and the traditional family structure. (Brumann). Instead of weakening familial ties in hopes of strengthening the society as a whole, the other communities studied by Brumann did both instead and were successful. He concludes his study by stating:

When it comes to active long-term survival ... communes built on monogamous marriage have proved more successful, and it is the three most impressive present-day communesthe Hutterite colonies, the kibbutzim, and the Bruderhof communities-that show the strongest sense of family and kinship. Moreover, the most promising alternative family policies are pursued by those contemporary groups that-owing to the influence of alternative cultureleave the question of partnership and family up to the members, and refrain from enforcing any unusual arrangements, but are still mainly monogamous. (417)

The combination of family and collectivism creating a positive impact is also seen within The Dispossessed through Shevek's own efforts to break free from the collectivist nature of his home planet and to form his own family. His long-term relationship with Takver causes him to strive for greatness throughout his life as she supports his endeavors, including his trip to Urras. When discussing the possibility of Shevek leaving Anarres for Urras, Takver states "Go to Urras .... Why not? They want you there. They don't here! Maybe they'll begin to see what they've lost, when you're gone. And you want to go. I saw that tonight. I never thought of it before, but when we talked about the prize, at dinner, I saw it, the way you laughed" (Le Guin 278). Takver's desire to assist Shevek in his decision and her support of his idea, even at the cost of never seeing him again, shows how the 
familial bonds Shevek has formed help to promote the creation of his communication device, which proves to be collectivist itself as it would benefit all planets. Without the strong familial bond between Shevek and Takver, Shevek may not have been able to convince himself to leave Anarres. Collectivism and familial bonds work together within Shevek's narrative, showing that neither one nor the other can exist on its own and be successful. American society currently promotes the traditional family structure over a more collectivist way of life, blind to the idea that incorporating both could be beneficial.

\section{CONTEMPORARY IMPLICATIONS}

The Dispossessed directly challenges the notion that feminism means the end to familial values as we know them. Through Shevek's story, Le Guin shows how both men and women alike can pursue endeavors outside of the home without the collapse of both families and society as a whole. The success of both Rulag and Shevek serve as an example of how the traditional familial structure can be altered and still provide positive results. Currently, American society holds that someone, mainly the mother, must remain in the home in order for children to be raised successfully. With a lack of funding for proper childcare and the negative stereotype of the "stay-at-home dad," America gives women little choice other than to remain at home with their children or face the scrutiny that comes with entering the workforce. If American society promoted the success of both men and women based on their ability to help the country, as shown by the collectivist example of Anarres, it would benefit greatly from their combined efforts. In order for this to occur, America would have to abandon the widely-held belief that a mother must remain in the home to raise her child or else the child will be at risk.

Although The Dispossessed is a fictional story, it redefines family by providing an alternative to the traditional American family structure that many defend to this day as the most effective way to raise children. Utopias like Anarres are expected to be "perfect" for their inhabitants, but in this pursuit, there will always be someone that suffers for the benefit of the society. In The Dispossessed, it can be easy to assume that there must be some victims of the collectivist, egalitarian societal structure of Anarres, and that these victims are the children who are raised by institutions as opposed to parents. Instead, Le Guin depicts success stories of both men and women who were raised through 
this structure. As feminism continues to force societies to change their ingrained social norms, novels such as The Dispossessed create an important representation of how societies might promote both familial values and feminist pursuits. Readers should not expect to find their ideas supported by literature; instead, they should expect to be challenged and ready to assess their own implicit biases and stereotypes. One can only hope that stories such as The Dispossessed continue to inspire readers to fight for the equality of all citizens and improve the quality of life of men and women alike. 


\section{WORKS CITED}

Brenner, Johanna. "Utopian Families." Necessary and Unnecessary Utopias, vol. 36, 2000, pp. 1-11. Socialist Register, https://socialistregister.com/index.php/srv/article/view/5738/2633.

Brumann, Christoph. "All the Flesh Kindred that Ever I See": A Reconsideration of Family and

Kinship in Utopian Communes." Comparative Studies in Society and History, vol. 45, no. 2, April 2003, pp. 395-421. CambridgeCore, https://doiorg.proxy.bsu.edu/10.1017/S0010 417503000197.

Gerson, Kathleen. "Resolving Family Dilemmas and Conflicts: Beyond Utopia." Contemporary Sociology, vol. 29, no. 1, Jan. 2000, pp 180-187. JSTOR, doi: 10.2307/2654942.

Lindow, Sandra J. “Mapping the Walls of The Dispossessed.” Extrapolation, vol. 52, no. 2, 2011, pp. 174-191. EBSCOhost, https://bsu.alma.exlibrisgroup.com/discovery/openurl? institution=o1BSU_INST\&vid=01BSU_INST:Services\&\%3Fctx_ver=Z39.882004\&ctx_ enc=info:ofi\%2Fenc:UTF8\&rfr_id=info:sid\%2Fsummon.serialssolutions.com\&rft_val_ fmt=info:ofi\%2Ffmt:kev:mtx:journal\&rft.genre=article\&rft.atitle=Mapping\%20the\%20 walls\%2oof\%2oThe\%2oDispossessed\&rft.jtitle=Extrapolation\&rft.au=Lindow,\%20Sandra\%20 J\&rft.date $=2011 \& r f t . i s s n=0014-5483 \& r f t . e i s s n=20477708 \& r f t . v o l u m e=52 \& r f t$. issue $=2 \& r f t$. spage $=174 \&$ rft.externalDocID=R04533482\&paramdict=en-US.

Le Guin, Ursula K. The Dispossessed. HarperCollins e-books, 1991. 